\title{
Screening of Lactic Acid Bacteria from Rumen Liquor and King Grass Silage as well as Their Antibacterial Activities
}

\author{
A. Sofyan ${ }^{\mathrm{a}, *}$, A. N. Aswari ${ }^{\mathrm{b}}$, T. Purwoko ${ }^{\mathrm{b}}$, \& E. Damayanti ${ }^{\mathrm{a}}$ \\ ${ }^{a}$ Division of Animal Feed \& Nutrition, Center for Processes Development \& Chemical Engineering (BPPTK), \\ Indonesian Institute of Sciences (LIPI) \\ Jln. Yogya-Wonosari Km. 31.5, Gading, Playen, Gunungkidul, D.I. Yogyakarta 55861, Indonesia \\ bDepartment of Biology, Faculty of Mathematics and Natural Sciences (FMIPA), Sebelas Maret University (UNS) \\ Jln. Ir. Sutami 36 A, Kentingan Surakarta 57126, Indonesia \\ (Received 23-09-2013; Reviewed 12-10-2013; Accepted 10-12-2013)
}

\begin{abstract}
Probiotic is a live microbial culture which has positive effect on animal by improving the natural balance of microflora in the digestive tract. This experiment aimed to screen and identify indigenous lactic acid bacteria (LAB) from rumen liquor and king grass (Pennisetum hybrid) silage as a probiotic candidate and to evaluate their resistance in low $\mathrm{pH}$, and inhibitory activities against pathogenic bacteria. The LAB isolate was characterized by a clear zone formed on MRSA medium $+\mathrm{CaCO}_{3} 0.2 \%$ $(w / v)$ and further identified by morphological and biochemical assays. The selected isolates were evaluated for their viability in low $\mathrm{pH}$, pathogenic bacterial inhibition, and lactic acid production. The experimental arrangement was a factorial block design $(4 \times 2)$ consisted of four isolates and two levels of $\mathrm{pH}$ value (pH 2 and 3), each treatment in 3 equal replicates. The result showed that four isolates (two isolates from the rumen liquor of fistulated cattle and two isolates from silage) were identified as lactic acid bacteria. The four isolates showed inhibition activity against Escherichia coli, Bacillus subtilis, Staphylococcus aureus and performed viability at low $\mathrm{pH}$ during $2 \mathrm{~h}$ treatment. The highest lactic acid production was obtained from isolates Sil.3 (21.42\%) and followed by CR2 (19.88\%), CR1 (15.40\%) and Sil.9 (15.08\%). Biochemical identification by standard of analytical profile index (API) 50 CHL kit showed that the selected isolates CR1 was Lactobacillus paracasei ssp. paracasei $3(91.5 \%)$, L. paracasei ssp. paracasei $3(76.5 \%)$, Sil.3 was Lactobacillus brevis (95.1\%), and Sil.9 was Lactobacillus collinoides (92.5\%). In conclusion, probiotic candidates isolated from rumen liquor are confirmed as L. paracasei ssp. paracasei (CR1 and CR2), while two other isolates from king grass silage are identified as L. brevis (Sil.3) and L. collinoides (Sil.9). L. brevis (Sil.3) and L. paracasei ssp. paracasei (CR1) has higher inhibition against pathogenic bacteria (E. coli, S. aureus, and B. subtilis) than L. paracasei ssp. paracasei (CR2) and L. collinoides (Sil.9).
\end{abstract}

Key words: isolation, probiotic, pathogenic bacteria, rumen liquor, silage

\section{ABSTRAK}

Probiotik merupakan kultur mikroba hidup yang dapat memberikan efek positif terhadap performa ternak dengan cara memperbaiki keseimbangan mikroorganisme alami di dalam saluran pencernaan. Penelitian ini bertujuan untuk mengisolasi, menyeleksi dan mengidentifikasi bakteri asam laktat (BAL) indigenos dari cairan rumen sapi dan silase rumput raja (Pennisetum hybrid) sebagai kandidat probiotik dengan mengetahui ketahanan beberapa isolat pada $\mathrm{pH}$ rendah dan aktivitas penghambatannya terhadap bakteri patogen. Isolat BAL dikarakterisasi daya hambatnya dengan metode cawan sebar pada media MRSA yang mengandung $\mathrm{CaCO} 30,2 \%$, dan identitifikasi dilakukan berdasarkan morfologi dan uji biokimia. Seleksi isolat dilakukan dengan mengukur viabilitas pada $\mathrm{pH}$ rendah, kemampuan menghambat bakteri patogen dan produksi asam laktat yang disusun dalam rancangan acak kelompok pola faktorial $(4 \times 2)$ yang terdiri atas empat jenis isolat dan 2 kondisi $\mathrm{pH}(\mathrm{pH} 2$ dan 3), setiap perlakuan terdiri atas 3 ulangan. Hasil penelitian mendapatkan empat isolat BAL (dua isolat berasal cairan rumen sapi dan dua isolat dari silase). Keempat isolat menunjukkan aktivitas penghambatan terhadap pertumbuhan bakteri patogen Escherichia coli, Bacillus subtilis, Staphylococcus aureus dan memiliki ketahanan hidup pada $\mathrm{pH}$ rendah ( $\mathrm{pH} 2$ dan 3) selama 2 jam. Produksi asam laktat tertinggi diperoleh dari isolat Sil.9 (21,42\%) dan CR2 (19,88\%) diikuti oleh CR1 (15,40\%) dan Sil.9 (15,08\%). Hasil identifikasi

${ }^{*}$ Corresponding author:

E-mail: sofyan_lipi@yahoo.co.id 


\begin{abstract}
biokimia menggunakan standar analytical profile index (API) 50 CHL Kit menunjukkan bahwa isolat CR1 adalah Lactobacillus paracasei ssp. paracasei (91,5\%), CR2 adalah L. paracasei ssp. paracasei (76,5\%), Sil.3. adalah Lactobacillus brevis $(95,1 \%)$ dan Sil.9 adalah Lactobacillus collinoides $(\mathbf{9 2 , 5 \% ) .}$ Kesimpulan dari penelitian ini, kandidat probiotik yang diisolasi dari cairan rumen adalah $L$. $p a-$ racasei ssp. paracasei (CR1 dan CR2), sedangkan dua isolat lainnya dari silase rumput raja adalah $L$. brevis (Sil.3) dan L. collinoides (Sil.9). L. brevis (Sil.3) dan L. paracasei ssp. paracasei (CR1) memiliki penghambatan terhadap bakteri patogen (E. coli, S. aureus, and B. subtilis) yang lebih tinggi dibanding L. paracasei ssp. paracasei (CR2) dan L. collinoides (Sil.9).
\end{abstract}

Kata kunci: isolasi, bakteri patogen, cairan rumen, probiotik, silase

\section{INTRODUCTION}

Since antibiotic had been banned for promoting animal growth in 2006, it implied an alternative substance to replace antibiotic by using organic additive based on natural compound, microbial culture or their combination. Due to consumer concerns to improve health and safety of animal products including those resulting from organic farming (European Commission, 2012). In fact, supply of animal product (e.g. milk production) is only covering $30 \%$ national demands and also the adequacy of meat supply needs to be increased by improvement of beef cattle productivity. Indonesian Ministry of Agriculture reported that milk production in 2010 was 0.90 million tones which only increased $9.94 \%$ from 2009 (Ditjen PKH, 2012) and also meat was imported to fulfill the national demand.

Beside the nutritional problem, ruminant disease caused by pathogenic bacteria such as Staphylococcus aureus, Escherichia coli and Bacillus subtilis implied on low production and immune-suppression of animals. S. aureus is known as a Gram positive bacteria, opportunistic pathogen and a major concern for both animal and human health (Charlier et al., 2009), and it has been found associated with certain gastrointestinal disease that is responsible for mastitis in dairy herds (Bouchard et al., 2013). E. coli infection caused disruptions of intercellular tight junctions, leading to clinical sequelae including acute diarrhea, hemorrhagic colitis, and the hemolyticuremic syndrome (Johnson-Henry et al., 2008). B. subtilis has also been reported associated with bovine mastitis although a limited number of cases (USEPA, 2012).

Administration of direct feed additive based microbes is potential to improve feed digestibility. Probiotic contains life microbial and favorable for improving the digestive tract function especially in digesting forage. Furthermore, probiotic is expected to modulate the immune system and inhibit pathogenic bacteria. Probiotics or direct feed microbes (DFM) are dietary supplements that inhibit gastrointestinal infection and provide optimally regulated microbial environments in the digestive tract (Seo et al., 2010). Administration of probiotics in livestock in the period of growth appears to be a real impact. Lactic acid bacteria as probiotic, are able to produce lactic acid, reuterin, diacetyl, bacteriocins and other metabolic functions as an antimicrobial (Rattanachaikunsopon \& Phumkhachorn, 2010), enhance fiber and starch digestion (Fraga et al., 2013) and improve animal health (Bayatkouhsar et al., 2013).
Lactic acid bacteria (LAB) ferments sugars or carbohydrates to produce large amounts of lactic acid. Lactic acid bacteria are naturally found in many different habitats such as fermented foods, fruits, grains, animal digestive tract or silage. In the digestive tract of cattle, lactic acid bacteria were found in the rumen (Bureenok et al., 2011; Cobos et al., 2011). Lactic acid bacteria in forage feed live as epiphytic bacteria in limited colony.

In order to optimize probiotic functions specific for host animal, administration of lactic acid isolated from indigenous sources will have promise more adaptable probiotic in the ruminant digestive tract. However, scientific publication related to exploration of indigenous microorganisms used as probiotics candidate from the host animal (rumen liquor) or animal feed (forages) is still limited. Therefore it has required to isolate and characterize lactic acid bacteria from cattle rumen and king grass (Pennisetum hybrid) silage and determine their antibacterial activity against pathogenic bacteria.

\section{MATERIALS AND METHODS}

\section{Sample Preparation}

Rumen liquor and king grass $(P$. hybrid) silage were prepared as inoculant sources. Rumen liquor was obtained from the fistulated cattle (Ongole Crossbred) which daily consumed diet consisted of forage and concentrate (70:30 dry matter basis). Silage was made from the chopped king grass which packed in a plastic bag and incubated during $21 \mathrm{~d}$ at room temperature (25-30 $\left.{ }^{\circ} \mathrm{C}\right)$ (Sofyan et al., 2011).

\section{Isolation and Screening of Lactic Acid Bacteria}

Collected fresh rumen liquor $(100 \mathrm{~mL})$ was strained through cheesecloth to obtain supernatant consisting microbial cells (rumen supernatant). Collected fresh silage (100 g) was added by $500 \mathrm{~mL}$ of distilled water and then mashed in a blender, then strained through cheesecloth to obtain supernatant. An amount of $50 \mathrm{ml}$ of supernatant was added by $1 \mathrm{~g}$ of d-glucose monohydrate $\left(\mathrm{C}_{6} \mathrm{H}_{2} \mathrm{O}_{6} \cdot \mathrm{H}_{2} \mathrm{O}\right)(\mathrm{w} / \mathrm{v})$ to stimulate the bacterial growth. Supernatant from the rumen and silage were grown on the selective medium of MRSA (de Man Rogosa Sharpe Agar) supplemented with $\mathrm{CaCO}_{3} 0.2 \%$ (w/v) using a spread plate method and anaerobically for $24 \mathrm{~h}$ at $37^{\circ} \mathrm{C}$ in an anaerocult chamber with an atmosphere of $\mathrm{CO}_{2}$. 
Primary screening of LAB was performed by evaluating the clear zones on selective medium. LAB colony with the largest clear zone diameter was chosen as the selected isolates.

\section{Characterization of Lactic Acid Bacteria}

Selected isolates from rumen liquor and king grass silage were characterized by catalase test, Gram staining, morphology, motility test, and gas production test. Motility test isolates was observed on SYP medium (sucrose-yeast extract-peptone), incubated for 24-48 h at $37{ }^{\circ} \mathrm{C}$. Gas production test performed by growing cultures in $5 \mathrm{~mL}$ of liquid SYP for $2-3 \mathrm{~d}$ at $37^{\circ} \mathrm{C}$ with a Durham tube which placed in reverse to capture the gas production (Damayanti et al., 2012).

\section{Viability in Low $\mathrm{pH}$}

The viability of lactic acid bacteria was evaluated by cultivating the isolate on acidity medium ( $\mathrm{pH} 2$ and $\mathrm{pH}$ 3). Evaluation of viability was arranged a factorial block design $(4 \times 2)$ consisted of the screened isolates (four isolates) and $\mathrm{pH}$ condition ( $\mathrm{pH} 2$ and 3), each treatment in 3 equal replications. Isolates were grown in MRS broth at $37{ }^{\circ} \mathrm{C}$ for $18 \mathrm{~h}$ then centrifuged using a refrigerated centrifuge 'Centrofriger ${ }^{\circledR}$ BL-II series' at $4137 \times g$ for $5 \mathrm{~min}$ at $4{ }^{\circ} \mathrm{C}$ to obtain the biomass (pelleted). Pelleted were washed twice with sterile phosphate buffered saline (PBS, $0.1 \mathrm{M}$ phosphate buffer with $0.8 \% \mathrm{NaCl}, \mathrm{pH}$ 7.0) referred to Bakari et al. (2011).

The strain was diluted 1/100 in sterile PBS adjusted to $\mathrm{pH} 2$ and 3 using $0.1 \mathrm{~N} \mathrm{HCl}$. Incubation times were 0 and $1 \mathrm{~h}$, then continued $2 \mathrm{~h}$ incubation in $\mathrm{pH} 3$ conditions. Serial decimal dilutions in sterile PBS were prepared, and aliquots $(0.1 \mathrm{~mL})$ from the dilutions was used for point inoculation on the surface of MRS agar plates to determine the number of surviving cells (Rehaiem et al., 2014).

The number of colonies were converted into log cfu/ $\mathrm{ml}$ for the calculation of viability percentage according to the following equation; [(Log cfu Nt) / (Log cfu N0) ] $x 100 \%$, where $\mathrm{Nt}$ represented total colonies at 1, $2 \mathrm{~h}$ and $\mathrm{N} 0$ represented total colonies at $0 \mathrm{~h}$ (Bao et al., 2010).

\section{The Growth Curve of Lactic Acid Bacteria and Lactic Acid Production}

Prior to cultivation LAB isolate into the medium, each of the four isolate was pre-cultured in MRSB, then incubated at $37^{\circ} \mathrm{C}$ for $24 \mathrm{~h}$ (culture stock). An amount of $1 \%(\mathrm{v} / \mathrm{v})$ culture stock was inoculated into MRSB using a Hungate tube then incubated at $37{ }^{\circ} \mathrm{C}$ for $48 \mathrm{~h}$ for analyzing growth kinetics. The control tube contained MRSB without the inoculation of LAB cultures. Bacterial growth was evaluated at $0,3,6,9,12,18,24,30,36$, and $48 \mathrm{~h}$ after incubation to obtain the optical density (OD) using a spectrophotometer (Dynamica ${ }^{\circledR}$ Halo RB10) at $\lambda_{625 \mathrm{~nm}}$. Viable cell was confirmed by spread plate count method to determine the number of colony at 0,24 , and $48 \mathrm{~h}$ after incubation. Total lactic acid and $\mathrm{pH}$ were measured at last incubation time (48 h). Measurement of lactic acid production was conducted by method referred to AOAC (2005) using the equation as followed; Where:
Vts : Volume of titrant sample $(\mathrm{mL})$
Vto: Volume of titrant blank (mL)
$\mathrm{N}$ : Normality of titrant $(0.1 \mathrm{~N} \mathrm{NaOH})$
$\mathrm{Mr}$ : Molecular weight of lactic acids $(90.0 \mathrm{~g} / \mathrm{mol})$
Df : Dilution factor (10x)
Vs : Volume of sample (mL)

\section{Antibacterial Activity Assay against Pathogenic Bacteria}

In vitro assay of $\mathrm{LAB}$ inhibition activities against pathogenic bacteria (E. coli FNCC 194, B. subtilis FNCC 0060, S. aureus FNCC 6049) were performed using agar diffusion methods (Bonev et al., 2008; Cizeikiene et al., 2013). The supernatant of $18 \mathrm{~h}$ from MRSB cultures was prepared using a refrigerated centrifuge 'Centrofriger ${ }^{\circledR}$ BL-II series ' at $4137 \times g$ for $5 \mathrm{~min}$ at $4{ }^{\circ} \mathrm{C}$. The supernatant was collected and neutralized by adding $0.5 \mathrm{~N} \mathrm{NaOH}$ up to $\mathrm{pH}$ 7. The antibacterial activities were observed using the paper disc diffusion method. The paper disc $(5 \mathrm{~mm})$ placed on the MRSA surface which was inoculated with $100 \mu \mathrm{L}$ pathogenic bacteria cultures and then embedded with $50 \mu \mathrm{L}$ of neutral LAB supernatant. Control was made by adding the antibiotic discs (15 mg Erithromycin, $10 \mathrm{mg}$ Penicillin G, $10 \mathrm{mg}$ Streptomycin) for each of the tested pathogenic bacteria. Observation of clear zones (inhibition zone) for $24 \mathrm{~h}$ at $37^{\circ} \mathrm{C}$.

\section{Biochemical Identification}

Biochemical tests were performed by fermentation pattern using standard analytical profile index (API 50 CHL, bioMérieux ${ }^{\circledR}$ ) using the manual standard of API CHL 50 kit (Muñoz-Quezada et al., 2013). Pure culture of LAB biomass from $24 \mathrm{~h}$ culture was inoculated into API $50 \mathrm{CHB} / \mathrm{E}$ medium. The result of the biochemical profile was used to identify the species of lactic acid bacteria using software product identification e.g. APIWEB (bioMérieux ${ }^{\circledR}$, Marcy l, Etoile, France).

\section{Data Analysis}

Qualitative data consisted of cell morphology and biochemical characteristic were analyzed using descriptive method. Data from quantitative parameter consisted of clear zone diameter, cell viability, lactic acid and $\mathrm{pH}$ were analyzed using analysis of variance (ANOVA) and followed by Duncan's Multiple Range Test to determine the effect of differences between treatments mean (Gomez \& Gomez, 2007). The statistical analyses of parameters were performed using the $\operatorname{CoSTAT}^{\circledR}$ Statistical Software (Cohort, 2008).

\section{RESULTS AND DISCUSSION}

\section{Isolation and Selection of Lactic Acid Bacteria}

In preliminary stage, LAB was screened by evaluating clear zone of each isolate grown on MRS 
Table 1. Clear zone diameter of colony grown on MRSA $+0.2 \%$ $\mathrm{CaCO}_{3}$

\begin{tabular}{ccc}
\hline \multirow{2}{*}{ Isolate number } & \multicolumn{2}{c}{ Inoculant sources } \\
\cline { 2 - 3 } & Rumen liquor $(\mathrm{CR})$ & Silage (Sil.) \\
\hline 1 & $2.13 ; 1.33^{*)}$ & $1.02 ; 0.67$ \\
2 & $2.19 ; 3.42^{*)}$ & $1.09 ; 1.62$ \\
3 & $2.45 ; 0.76$ & $0.96 ; 2.02^{*)}$ \\
4 & $1.41 ; 2.06$ & $0.78 ; 1.67$ \\
5 & $1.18 ; 1.43$ & $1.19 ; 1.77$ \\
6 & $1.22 ; 0.64$ & $1.12 ; 0.94$ \\
7 & $0.83 ; 0.86$ & $0.79 ; 1.31$ \\
8 & $0.93 ; 1.79$ & $0.78 ; 0.67$ \\
9 & $1.93 ; 1.74$ & $\left.1.01 ; 1.94^{*}\right)$ \\
10 & $1.11 ; 1.78$ & $0.68 ; 0.57$ \\
\hline
\end{tabular}

Note: *) The selected isolate based on the largest of clear zone, the value indicated that two clear zones.

agar. Initial screening were obtained 2 isolates from rumen liquor (CR), 2 isolates silage (Sil). The clear zone diameter of the selected isolates consisted of CR1, CR2, Sil.3, and Sil.9 are presented in Table 1. Characterization of the screened isolates consisted of catalase test, Gram staining, morphology, motility test, and gas production test are shown in Table 2.

Resistance of lactic acid bacteria in low $\mathrm{pH}$ was performed by cultivation isolates on a medium that was adjusted at $\mathrm{pH} 2$ and 3 for 0 and $1 \mathrm{~h}$. Viability of four isolates were affected by $\mathrm{pH}$ and incubation time significantly $(\mathrm{P}<0.05)$. However, there was no interaction $(\mathrm{P}>0.05)$ between isolates and medium acidity condition ( $\mathrm{pH}$ value) on cell viability. Based on the viability in pH 2 and 3 indicated that the four isolates were able to survive in low $\mathrm{pH}$ condition (Table 3).

A number of initial colonies were similar around 5.00-6.42 $\log \mathrm{cfu} / \mathrm{mL}$. Incubation time for $1 \mathrm{~h}$ showed that percentage of isolates colonies survived in $\mathrm{pH} 2$ was $68 \%$ for CR1 and CR2, followed by Sil.3 and Sil.9. Meanwhile, the percentage of isolates colonies survived in $\mathrm{pH} 3$ were $89 \%, 66 \%, 65 \%$, and $63 \%$ respectively for CR2, Sil.9, CR1, and Sil.3. Furthermore, incubation time for $2 \mathrm{~h}$ in $\mathrm{pH} 3$ showed that viability of fourth isolates were not significantly different. In general, the highest viability of isolates obtained from CR1, the lowest obtained from Sil.9, except for CR1 and Sil.3 were similar. It is indicated that CR2 was more able to survive in low $\mathrm{pH}$ than other isolates, consequently it could be used as a probiotic candidate.

An ability bacterium to survive in acid medium was closely related to cell stability which was influenced by many factors consisted of temperature, $\mathrm{pH}$ and nutrient availability. Moreover, adaptability bacteria in environmental condition were closely affected on growth and survivability. Romero-Pérez et al. (2011) revealed that environmental factor influenced ability bacteria to grow in acidity medium which was related to previous natural habitats.

In general, the pattern of LAB growth following sigmoid curve (S) was measured by turbidimetry method (Optical Density/OD) and further confirmed by total plate count (TPC) to evaluate the cell viability (Hogg, 2013; Rehaiem et al., 2014). The growth rate was indi-

Table 2. Characterization of the selected isolate

\begin{tabular}{|c|c|c|c|c|c|}
\hline \multirow{2}{*}{ Isolates } & \multicolumn{3}{|c|}{ Morphological test } & \multirow{2}{*}{ Motility } & \multirow{2}{*}{$\begin{array}{l}\text { Gas production tes } \\
\text { (fermentation type) }\end{array}$} \\
\hline & Gram & Catalase & Shape & & \\
\hline CR1 & Positive & Negative & Rod & Non-motile & Heterofermentative \\
\hline CR2 & Positive & Negative & Rod & Non-motile & Homofermentative \\
\hline Sil.3 & Positive & Negative & Rod & Non-motile & Homofermentative \\
\hline Sil.9 & Positive & Negative & Rod & Non-motile & Heterofermentative \\
\hline
\end{tabular}

Table 3. Cell viability of isolates incubated at low pH during 0,1 , and $2 \mathrm{~h}$

\begin{tabular}{|c|c|c|c|c|c|c|c|c|c|}
\hline \multirow{2}{*}{ Isolates } & \multicolumn{2}{|c|}{ Initial colonies $(0 \mathrm{~h})$} & \multicolumn{2}{|c|}{ Viability $(0 \mathrm{~h})$} & \multicolumn{2}{|c|}{ Viability after $1 \mathrm{~h}$} & \multicolumn{2}{|c|}{${ }^{*}$ Viability after $2 \mathrm{~h}$} & \multirow{2}{*}{$\begin{array}{c}\text { Average } \\
\text { (Isolate factor) }\end{array}$} \\
\hline & $\mathrm{pH} 2$ & pH 3 & pH 2 & $\mathrm{pH} 3$ & pH 2 & pH 3 & ${ }^{* *} \mathrm{pH} 2$ & pH 3 & \\
\hline CR1 & $6.39 \pm 1.1$ & $6.06 \pm 0.8$ & $100.0 \pm 0.0$ & $100.0 \pm 0.0$ & $68.3 \pm 03.5$ & $65.0 \pm 32.1$ & nd & $52.5 \pm 4.7$ & $83.3 \pm 21.6$ \\
\hline CR2 & $5.26 \pm 0.2$ & $5.00 \pm 0.8$ & $100.0 \pm 0.0$ & $100.0 \pm 0.0$ & $68.9 \pm 14.5$ & $89.8 \pm 25.8$ & nd & $53.2 \pm 16.8$ & $89.7 \pm 17.6$ \\
\hline Sil.3 & $5.35 \pm 0.1$ & $6.07 \pm 0.5$ & $100.0 \pm 0.0$ & $100.0 \pm 0.0$ & $38.3 \pm 54.2$ & $62.5 \pm 21.0$ & nd & $31.0 \pm 43.9$ & $75.2 \pm 35.6$ \\
\hline Sil.9 & $5.02 \pm 1.4$ & $6.42 \pm 0.2$ & $100.0 \pm 0.0$ & $100.0 \pm 0.0$ & $60.4 \pm 12.2$ & $66.4 \pm 5.9$ & nd & $15.5 \pm 21.9$ & $81.6 \pm 21.3$ \\
\hline \multicolumn{2}{|c|}{ Incubation (block) } & $(0 \mathrm{~h})$ & $100.0 \pm 0.0^{\mathrm{a}}$ & (after $1 \mathrm{~h}$ ) & $64.9 \pm 23.8^{\mathrm{b}}$ & & & & \\
\hline \multicolumn{2}{|l|}{$\mathrm{pH}$ factor } & $(\mathrm{pH} 2)$ & $79.5 \pm 27.7^{\mathrm{a}}$ & (pH 3) & $85.4 \pm 20.9^{a}$ & & & & \\
\hline \multicolumn{2}{|c|}{ Interaction } & \multicolumn{3}{|c|}{ Isolat $\mathrm{x} \mathrm{pH}=$ non significant $(\mathrm{P}=0.877)$} & & & & & \\
\hline
\end{tabular}

Note: Mean in the same row with different superscripts differ significantly $(\mathrm{P}<0.05)$. Initial colonies was similar population in log cfu/mL $(\mathrm{P}>0.05)$.

${ }^{*}$ Data from the cell viability assessment after $2 \mathrm{~h}$ was not included in average calculation and statistical analysis. ${ }^{* *}$ nd : not available data. 
cated from absorbance of $48 \mathrm{~h}$ incubation at $37^{\circ} \mathrm{C}$. Based on the Figure 1, the high growth rate of LAB isolates was CR2, and Sil.3. Bacterial growth was influenced by $\mathrm{pH}$, nutrient content, and temperature. The population of LAB after $48 \mathrm{~h}$ incubation showed that CR2 and Sil.3 were similar and higher than others (Figure 2). Cousin et al. (2012) stated that lactic acid bacteria require carbon and nitrogen sources for optimizing growth and produce lactic acid as major metabolites. Characteristic of fermentability from each isolate to ferment medium (glucose and its derivatives) was explained in Table 4.

At the end of incubation ( $48 \mathrm{~h}$ ), levels of lactic acid and $\mathrm{pH}$ of the medium were measured to determine the type of fermentation from each isolate which obtained from the gas production test as shown in Table 2. Hogg (2013) stated that lactic acid levels are different depending on the type of fermentation. A homofermentative type of lactic acid bacteria produces high levels of lactic acid due to converting 95\% glucose into lactic acid, a small amount of $\mathrm{CO}_{2}$ and volatile acids. While the heterofermentative types of lactic acid bacteria produce lactic acid in low concentration and amount of $\mathrm{CO}_{2}$.

Based on the test results of fermentation type, isolates CR2, and Sil.3 were homofermentative that had high levels of lactic acid. Isolates CR1 and Sil.9 had low levels of lactic acid and indicated heterofermentative type. Levels of lactic acid production were closely related to $\mathrm{pH}$ value. König \& Fröhlich (2009) stated that fermentation type of lactic acid produced dominantly lactic acid was a homofermentative however heterofermentative of LAB produce not only lactic acid but also acetic or alcohol.

Biochemical characteristic of LAB evaluated using API CHL 50 are presented in Table 5. All of the isolates have a similar result from sugar fermentation test on API CHL 50 except for substrates consisted of D-galactose, D-lactose, D-Saccharose, inulin and D-rafinose. Based on analysis using software APIWEB (Table 6), isolates CR1 was Lactobacillus paracasei ssp. paracasei 3 (91.5\%),
CR2 was Lactobacillus paracasei ssp. paracasei 3 (76.5\%), Sil.3 was Lactobacillus brevis (95.1\%), and Sil.9 was Lactobacillus collinoides (92.5\%). Lactic acid bacteria require different carbohydrate sources for growth and to produce substances that can be used to defend cells from pathogenic bacteria invasions (bacteriocins).

This biochemical test result supported by Gulahmadov et al. (2009) revealed that L. brevis, and L. collinoides were isolated from Azerbaijan cheeses have activity to ferment D-ribose, D-glucose, D-fructose, N-acetyglucosamine, D-Maltose, D-trehalosa, however, D-celobiose, D-lactose, sucrose and innulin were only fermented by L. brevis. Muñoz-Quezada et al. (2013) identified Lactobacillus paracasei which was able to utilize inulin and sucrose. Although phenotypic identification using a biochemical test is accurate methods, molecular identification need to conduct for the confirmation of bacteria species as a probiotic candidate (Ouoba et al., 2010).

\section{Inhibitory Against Pathogenic Bacteria}

The inhibition activity from tested isolates was showed by clear zone diameter (Figure 3). Antimicrobial assay results indicated that the isolates were able to inhibit the growth of pathogenic bacteria. Based on the data, all isolates inhibited B. subtilis. LAB isolated

Table 4. Lactic acid production and $\mathrm{pH}$ of media inoculated with the selected isolates

\begin{tabular}{ccc}
\hline Isolate & Lactic acid $(\%)$ & $\mathrm{pH}$ \\
\hline CR1 & $15.40 \pm 1.56^{\mathrm{b}}$ & $4.03 \pm 0.01^{\mathrm{b}}$ \\
CR2 & $19.88 \pm 0.81^{\mathrm{a}}$ & $3.75 \pm 0.02^{\mathrm{c}}$ \\
Sil.3 & $21.42 \pm 0.14^{\mathrm{a}}$ & $3.71 \pm 0.02^{\mathrm{d}}$ \\
Sil.9 & $15.08 \pm 0.25^{\mathrm{b}}$ & $4.18 \pm 0.01^{\mathrm{a}}$ \\
\hline
\end{tabular}

Note: Mean in the same column with different superscripts differ significantly $(\mathrm{P}<0.05)$.

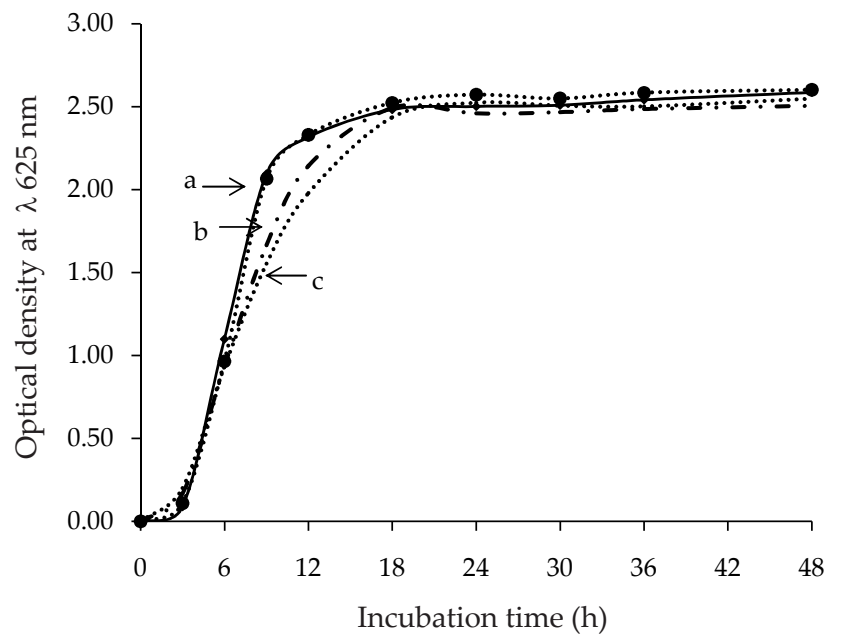

Figure 1. Growth curve of isolates $(\cdots \cdots \cdots$ for CR1, …. $\cdots .$. for CR2, - - for Sil. 3, . - f for Sil. 9) during $48 \mathrm{~h}$ of incubation. a, b, c indicated significant difference $(\mathrm{P}<0.05)$.

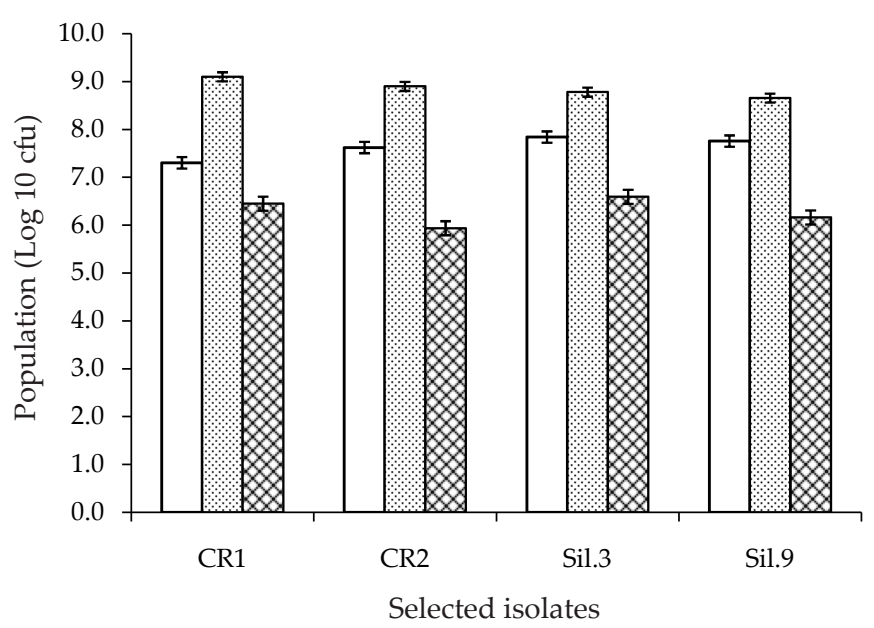

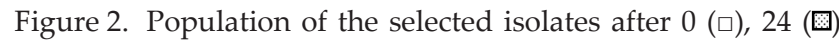
and $48(\mathbb{Q})$ h of incubation 
Table 5. Biochemical identification of the selected isolates using API 50 CHL Kit

\begin{tabular}{|c|c|c|c|c|c|c|c|c|c|c|c|}
\hline \multirow{2}{*}{ No } & \multirow{2}{*}{ Type of substrate test } & \multicolumn{4}{|c|}{ Reaction of isolates } & \multirow{2}{*}{ No } & \multirow{2}{*}{ Type of substrate test } & \multicolumn{4}{|c|}{ Reaction of isolates } \\
\hline & & CR1 & CR2 & Sil.3 & Sil.9 & & & CR1 & CR2 & Sil.3 & Sil.9 \\
\hline 0 & Control & - & - & - & - & 25 & Esculin ferric citrate & + & + & + & + \\
\hline 1 & Glycerol & - & - & - & - & 26 & Salicin & + & + & + & + \\
\hline 2 & Erythritol & - & - & - & - & 27 & D-celibiose & + & + & + & + \\
\hline 3 & D-arabinose & - & - & - & - & 28 & D-maltose & + & + & + & + \\
\hline 4 & L-arabinose & - & - & - & - & 29 & D-lactose(bovin arginin) & + & + & - & + \\
\hline 5 & D-ribose & + & + & + & + & 30 & D-melibiose & - & - & - & - \\
\hline 6 & D-xylose & - & - & - & - & 31 & D-saccharose (sucrose) & + & + & - & + \\
\hline 7 & L-xylose & - & - & - & - & 32 & D-trehalose & + & + & + & + \\
\hline 8 & D-adonitol & - & - & - & - & 33 & Inulin & + & - & - & + \\
\hline 9 & Methyl-bd-xylopyranoside & - & - & - & - & 34 & D-melezitose & - & - & - & - \\
\hline 10 & D-galactose & - & + & + & - & 35 & D-raffinose & + & - & + & + \\
\hline 11 & D-glucose & + & + & + & + & 36 & Amidon (starch) & - & - & - & - \\
\hline 12 & D-fructose & + & + & + & + & 37 & Glycogen & - & - & - & - \\
\hline 13 & D-mannose & + & + & + & + & 38 & Xylitol & - & - & - & - \\
\hline 14 & L-sorbose & - & - & - & - & 39 & Gentibiose & + & + & + & + \\
\hline 15 & L-rhamnase & - & - & - & - & 40 & D-turanose & - & - & - & - \\
\hline 16 & Dulcitol & - & - & - & - & 41 & D-lyxose & - & - & - & - \\
\hline 17 & Inositol & - & - & - & - & 42 & D-tagatose & + & + & + & + \\
\hline 18 & D-mannitol & + & + & + & + & 43 & D-fucose & - & - & - & - \\
\hline 19 & D-sorbitol & + & + & + & + & 44 & L-fucose & - & - & - & - \\
\hline 20 & Methil-aD-mannopyranoside & - & - & - & - & 45 & D-arabitol & - & - & - & - \\
\hline 21 & Methyl-aD-glucopyranoside & - & - & - & - & 46 & L-arabitol & - & - & - & - \\
\hline 22 & $\mathrm{~N}$-acetylglucosamine & + & + & + & + & 47 & Potassium gluconate & - & - & - & - \\
\hline 23 & Amygdalin & + & + & + & + & 48 & Potassium-2 celogluconate & - & - & - & - \\
\hline 24 & Arbutin & + & + & + & + & 49 & Potassium-5 celogluconate & + & + & + & + \\
\hline
\end{tabular}

Note: + : positive reaction (red changed into yellow color) , - : negative reaction (red color not changed)

Table 6. Species identification results analyzed by APIWEB software

\begin{tabular}{cccl}
\hline No & $\begin{array}{c}\text { Isolate } \\
\text { code }\end{array}$ & $\begin{array}{c}\text { Significant } \\
\text { taxa value }\end{array}$ & \multicolumn{1}{c}{ Species name } \\
\hline 1 & CR1 & $91.50 \%$ & $\begin{array}{l}\text { Lactobacillus paracasei ssp. } \\
\text { paracasei 3 } \\
\text { Lactobacillus brevis 1 } \\
\end{array}$ \\
2 & CR2 & $\begin{array}{l}5.10 \% \\
76.50 \%\end{array}$ & $\begin{array}{l}\text { Lactobacillus paracasei ssp. } \\
\text { paracasei 3 }\end{array}$ \\
& & $21.50 \%$ & $\begin{array}{l}\text { Lactobacillus brevis 1 } \\
\text { Lactobacillus brevis }\end{array}$ \\
3 & Sil.3 & $95.10 \%$ & $\begin{array}{l}\text { Lactobacillus paracasei ssp. } \\
\text { paracasei 3 } \\
\text { Lactobacillus collinoides }\end{array}$ \\
& & $4.20 \%$ & Lactobacillus lactis ssp. lactis 1 \\
\hline
\end{tabular}

from rumen liquor (CR1 and CR2) had higher inhibition against E. coli than silage isolate, however isolate Sil.3 had the highest inhibition activity againts $S$. aureus.

The difference ability of the isolates to inhibit patho-

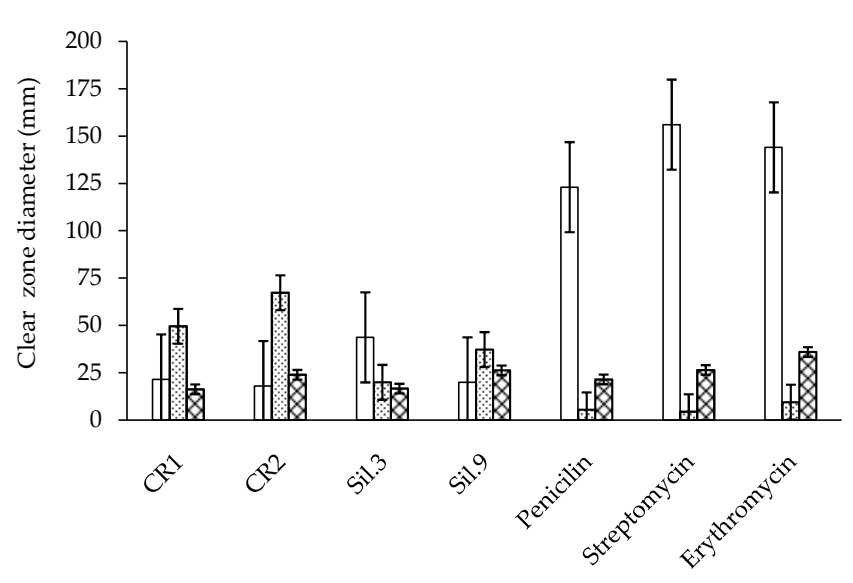

Figure 3. Antibacterial activity of LAB isolates and antibiotics (control) against pathogenic bacteria. S. aureus ( $\square$ ), E. coli (國) and B. subtilis ( $($ ).

genic bacteria could be influenced by many factors such as lactic acid and bacteriocine production from LAB and resistence of pathogenic bacteria to grow at low $\mathrm{pH}$ (acid stress). Acidity condition can damage the mem- 
brane cytoplasmic Gram negative bacteria. Due to Gram positive bacteria cell encapsulated by thick layer of peptidoglycan that strengthened cell wall (Derouaux et al., 2014). It implied ability LAB to inhibit gram positive bacteria (S. aureus and B. subtilis) seem lower than gram negative pathogenic bacteria (E. coli). Acuña et al. (2012) revealed that an antimicrobial petide 'microcins' had better performance killing E. coli (Gram negative) than Listeria innocua (Gram positive) cells.

Charlier et al. (2009) reported that bacteriocinproducing strains are indeed of considerable interest for the preservation of fermented products which may be achieved by inhibiting the growth of pathogens such as Listeria monocytogenes and/or S. aureus. Vlková et al. (2010) reported that lactic acid bacteria have antimicrobial activity, and were bile and acid tolerant; they exhibited a decrease in viability $<1 \log \mathrm{CFU} / \mathrm{mL}$ after incubation for $3 \mathrm{~h}$ for bile tolerance and $2 \mathrm{~h}$ for low $\mathrm{pH}$ tolerance significantly lower amounts of E. coli. In recent studies, application of $8.0 \log \mathrm{cfu} / \mathrm{g}$ LAB produced significant reductions in E. coli O157:H7 (Cálix-Lara et al., 2014). Moreover, Arief et al. (2013) studied that LAB (L. plantarum) was able to produce antimicrobial 'plantaricin' peptide which inhibited pathogenic bacteria (E. coli, B. cereus, S. aureus and S. thypimurium).

The highest inhibition of antibiotic against $S$. aureus growth was closely related to a spectrum of antibiotic activity. Based on Figure 3, Penicilin, Streptomycin and Erythromycin seem to have higher inhibition against $S$. aureus growth than $\mathrm{LAB}$ metabolite. Compare to chemical antibiotic, pathogenic bacteria inhibition by LAB metabolite was related to the chemical antibiotic compound in pure substance and the ability of antibiotic to penetrate pathogenic bacteria cell easily (Bonev et al. 2008), however antibacterial substance from lactic acid bacteria as probiotic was more safety than antibiotic due to its lower risk of residual and has no resistance effect on pathogenic bacteria.

\section{CONCLUSION}

Lactic acid bacteria isolated from rumen liquor and king grass ( $P$. hybrid) could be used as probiotic. Probiotic candidates isolated from rumen liquor are confirmed as L. paracasei ssp. paracasei (CR1 and CR2), while two other isolates from king grass silage are identified as L. brevis (Sil.3) and L. collinoides (Sil.9). Lactobacillus brevis (Sil.3) and L. paracasei ssp. paracasei (CR1) has higher inhibition against pathogenic bacteria (Escherichia coli, Staphylococcus aureus, and Bacillus subtilis) than L. paracasei ssp. paracasei (CR2) and L. collinoides (Sil.9).

\section{ACKNOWLEDGEMENT}

The authors would like to thank to the Feed Additive Thematic Research FY 2013 LIPI (DIPA079.01.2.4501714/2013) for supporting the research materials. We also appreciated Mrs. Lusty Istiqomah for assisting correction of manuscript, the head of UPT BPPTK LIPI and Technician Staff for facilitating and assisting this research.

\section{REFERENCES}

Acuña, L., G. Picariello, F. Sesma, R. D. Morero, \& A. Bellomio. 2012. A new hybrid bacteriocin, Ent35-MccV, displays antimicrobial activity against pathogenic Grampositive and Gram-negative bacteria. FEBS Open Bio. 2: 12-19. http://dx.doi.org/10.1016/j.fob.2012.01.002

AOAC. 2005. Official Methods of Analysis. In: K. Helrich (Ed.) $15^{\text {th }}$ Edition, Association of Official Analytical Chemists. Arlington, V.A.

Arief, I. I., Jakaria, T. Suryati, Z. Wulandari, \& E. Andreas. 2013. Isolation and characterization of plantaricin produced by Lactobacillus plantarum strains (IIA-1A5, IIA-1B1, IIA-2B2). Med. Pet. 36:91-100. http://dx.doi.org/10.5398/ medpet.2013.36.2.91

Bakari, D., N. L. Tatsadjieu, A. Mbawala, \& C. M. Mbofung. 2011. Assessment of physiological properties of some lactic acid bacteria isolated from the intestine of chickens use as probiotics and antimicrobial agents against enteropathogenic bacteria. Innov. Romanian Food Biotechnol. 8: 33-40. (Available at http://www.bioaliment.ugal.ro/ejournal.htm)

Bao, Y., Y. Zhang, Y. Zhang, Y. Liu, S. Wang, X. Dong, Y. Wang, \& H. Zhang. 2010. Screening of potential probiotic properties of Lactobacillus fermentum isolated from traditional dairy products. Food Control 21: 695-701. http://dx.doi. org/10.1016/j.foodcont.2009.10.010

Bayatkouhsar, J., A. M. Tahmasebi, A. A. Naserian, R. R. Mokarram, \& R. Valizadeh. 2013. Effects of supplementation of lactic acid bacteria on growth performance, blood metabolites and fecal coliform and lactobacilli of young dairy calves. Anim. Feed Sci. Technol. 186 (1-2): 1-11. http://dx.doi.org/10.1016/j.anifeedsci.2013.04.015

Bonev, B., J. Hooper, \& J. Parisot. 2008. Principles of assessing bacterial susceptibility to antibiotics using the agar diffusion method. J. Antimicrob. Chemother. 61: 1295-1301. http://dx.doi.org/10.1093/jac/dkn090

Bouchard, D. S., L. Rault, N. Berkova, Y. L. Loir, \& S. Even. 2013. Inhibition of Staphylococcus aureus invasion into bovine mammary epithelial cells by contact with live Lactobacillus casei. Appl. Environ. Microbiol. 79: 877-885. http://dx.doi.org/10.1128/AEM.03323-12

Bureenok, S., W. Suksombat, \& Y. Kawamoto. 2011. Effects of the fermented juice of epiphytic lactic acid bacteria (FJLB) and molasses on digestibility and rumen fermentation characteristics of ruzigrass (Brachiaria ruziziensis) silages. Livest. Sci. 138: 266-271. http://dx.doi.org/10.1016/ j.livsci.2011.01.003

Cálix-Lara, T. F., M. Rajendran, S. T. Talcott, S. B. Smith, R. K. Miller, A. Castillo, J. M. Sturino, \& T. M. Taylo. 2014. Inhibition of Escherichia coli O157:H7 and Salmonella enterica on spinach and identification of antimicrobial substances produced by a commercial lactic acid bacteria food safety intervention. Food Microbiol. 38: 192-200. http://dx.doi. org/10.1016/j.fm.2013.09.006

Charlier, C., M. Cretenet, S. Even, \& Y. L. Loir. 2009. Interactions between Staphylococcus aureus and lactic acid bacteria: an old story with new perspectives. Int. J. Food Microbiol. 131: 30-39. http://dx.doi.org/10.1016/j.ijfoodmicro.2008.06. 032.

Cizeikiene, D., G. Juodeikiene, A. Paskevicius, \& E. Bartkiene. 2013. Antimicrobial activity of lactic acid bacteria against pathogenic and spoilage microorganism isolated from food and their control in wheat bread. Food Control 31 (2): 539-545. http://dx.doi.org/10.1016/j.foodcont.2012.12.004

Cobos, M. A., A. L. deCoss, N. D. Ramirez, S. S. Gonzalez, \& R. F. Cerrato. 2011. Pediococcus acidilactici isolated from the rumen of lambs with rumen acidosis, 16S rRNA identification and sensibility to monensin and lasalocid. Res. Vet. 
Sci. 90: 26-30. http://dx.doi.org/10.1016/j.rvsc.2010.05.006

Cohort. 2008. CoSTAT Version 6.400. Copyright 1998-2008. Cohort Software. 798. Lighthouse Ave, Montere, CA. 93940. USA.

Cousin, F. J., B. Foligne', S. M. Deutsch, S. Massart, S. Parayre, Y. L. Loir, G. Boudry, \& G. Jan. 2012. Assessment of the probiotic potential of a dairy product fermented by Propionibacterium freudenreichii in piglets. J. Agric. Food Chem. 60: 7917-7927. http://dx.doi.org/10.1021/jf302245m.

Damayanti, E., H. Herdian, M. Angwar, A. Febrisiantosa, \& L. Istiqomah. 2012. Lactic acid bacterial screening from gastrointestinal digestive tract of native and broiler chicken for probiotic candidate purposes. J. Indon. Trop. Anim. Agric. 37: 168-175. (Available at http://www.jppt.undip. ac.id).

Derouaux, A., M. Terrak, T. den Blaauwen, \& W. Vollmer. 2014. Bacterial cell growth, shape and division. In: Remaut, H., \& R. Fronzes, (Eds.). Bacterial Membranes: Structural and Molecular Biology. Caister Academic Press, Norfolk, UK. Pp. 3-54.

Europen Commission [EC]. 2012. Plants and their extracts and other natural alternatives to antimicrobials in feeds. http:// ec.europa.eu/research/health/infectious-diseases/antimicrobial-drug-resistance/projects/068_en.html [01/03/2012].

Fraga, M., K. Perelmuter, M. J. Valencia, M. Martínez, A. AbinCarriquiry, C. Cajarville, \& P. Zunino. 2013. Evaluation of native potential probiotic bacteria using an in vitro ruminal fermentation system. Ann. Microbiol. 1-8. http://dx.doi. org/10.1007/s13213-013-0753-3

Ditjen PKH (General Directorate of Livestock \& Animal Health). 2012. Livestock and Animal Health Statistic 2011. Indonesian Ministry of Agriculture, Jakarta.

Gomez, K. A. \& A. A. Gomez. 2007. Procedure of Statistics for Agricultural Research. Second Edition (Indonesian Translation). University of Indonesia-Press, Jakarta.

Gulahmadov, S. G., N. F. Abdullaeva, N. F. Guseinova, A. A. Kuliev, I. V. Ivanova, M. Dalgalarondo, J. M. Chobert, \& T. Haertlée. 2009. Isolation and characterization of bacteriocin-like inhibitory substances from lactic acid bacteria isolated from Azerbaijan cheeses. Appl. Biochem. Microbiol. 45: 297-303. http://dx.doi.org/10.1134/S0003683809030053

Hogg, S. 2013. Essential Microbiology. $2^{\text {nd }}$ Edition. John Wiley \& Sons Ltd, Chichester, West Sussex, England. UK.

Johnson-Henry, K. C., K. A. Donato, G. Shen-Tu, M. Gordanpour, \& P. M. Sherman. 2008. Lactobacillus rhamnosus strain GG prevents enterohemorrhagic Escherichia coli O157:H7-induced changes in epithelial barrier function. Infect. Immun. 76: 1340-1348. http://dx.doi.org/10.1128/ IAI.00778-07

König, H. \& J. Fröhlich. 2009. Lactic acid bacteria. In: König, H., G. Unden, \& J. Fröhlich (Eds.). Biology of Microorganisms on Grapes, in Must and in Wine. Springer. http://www. springer.com/978-3-540-85462-3. [17/07/2013]

Muñoz-Quezada, S., E. Chenoll, J. M. Vieites, S. Genovés, J. Maldonado, M. Bermúdez-Brito, C. Gomez-Llorente, E. Matencio, M. J. Bernal, F. Romero, A. Suárez, D. Ramón, \& A. Gil. 2013. Isolation, identification and characterisation of three novel probiotic strains (Lactobacillus paracasei CNCM I-4034, Bifidobacterium breve CNCM I-4035 and Lactobacillus rhamnosus CNCM I-4036) from the faeces of exclusively breast-fed infants. Br. J. Nutr. 109 (Suppl 2): S51-62. http://dx.doi.org/10.1017/S0007114512005211

Ouoba, L. I. I., C. A. G. Nyanga-Koumou, C. Parkouda, H. Sawadogo, S. C. Kobawila, S. Keleke, B. Diawara, D. Louembe, \& J. P. Sutherland. 2010. Genotypic diversity of lactic acid bacteria isolated from African traditional alkaline-fermented foods. J. Appl. Biol. 108: 2019-2029. http:// dx.doi.org/10.1111/j.1365-2672.2009.04603.x

Rattanachaikunsopon, P. \& P. Phumkhachorn. 2010. Lactic acid bacteria: their antimicrobial compounds and their uses in food production. Ann. Biol. Res. 1 (4): 218-228. (Available at http://scholarsresearchlibrary.com/archive.html).

Rehaiem, A., Z. B. Belgacem, M. R. Edalatian, B. Martínez, A. Rodríguez, M. Manai, \& N. P. Guerra. 2014. Assessment of potential probiotic properties and multiple bacteriocin encoding-genes of the technological performing strain Enterococcus faecium MMRA. Food Control. 37: 343-350. http://dx.doi.org/10.1016/j.foodcont.2013.09.044

Romero-Pérez, G. A., K. H. Ominski, T. A. McAllister, \& D. O. Krause. 2011. Effect of environmental factors and influence of rumen and hindgut biogeography on bacterial communities in steers. Appl. Environ. Microbiol. 77:258268. http://dx.doi.org/10.1128/AEM.01289-09

Seo, J. K., S. W. Kim, M. H. Kim, S. D. Upadhaya, D. K. Kam, \& J. K. Ha. 2010. Direct-fed microbials for ruminant animals. Asian-Aust. J. Anim. Sci. 23: 1657-1667. (Available at http://www.ajas.net).

Sofyan, A., L. M. Yusiati, Y. Widyastuti, \& R. Utomo. 2011. Microbiological characteristic and fermentability of king grass (Pennisetum hybrid) silage treated by lactic acid bacteria-yeast inoculants consortium combined with rice bran addition. Indon. J. Trop. Anim. Agric. 36: 265-272. (Available at http://www.jppt.undip.ac.id).

USEPA (United State Environmental Protection Agency). 2012. Bacillus subtilis final risk assessment. Biotechnology Program under the Toxic Substances Control Act (TSCA). http://epa.gov/biotech_rule/pubs/fra/fra009.htm [27/09/2012].

Vlková, E., M. Grmanová, J. Killer, J. Mrázek, J. Kopečný, \& V. Bunešová. 2010. Survival of bifidobacteria administered to calves. Folia Microbiol. 55: 390-392. http://dx.doi. org/10.1007/s12223-010-0066-x 